\title{
Consciousness as Inner Sensation: Crusius and Kant
}

JONAS JERVELL INDREGARD

Sun Yat-Sen University

\begin{abstract}
What is it that makes a mental state conscious? Recent commentators have proposed that for Kant, consciousness results from differentiation: A mental state is conscious insofar as it is distinguished, by means of our conceptual capacities, from other states or things. I argue instead that Kant's conception of state consciousness is sensory: A mental state is conscious insofar as it is accompanied by an inner sensation. Interpreting state consciousness as inner sensation reveals an underappreciated influence of Crusius on Kant's view, solves some long-standing puzzles concerning Kant's difficult doctrine of self-affection, and sheds light on his theory of inner experience.
\end{abstract}

\section{Introduction}

This article investigates Immanuel Kant's account of what is today called state consciousness: that which makes a mental state conscious as opposed to nonconscious. Kant is famous for his difficult and important theory of the unity of consciousness, and of the particular kind of self-consciousness involved in what he calls transcendental apperception. His account of state consciousness, by contrast, has received less attention. Recent studies have moreover suggested that Kant's theory of state consciousness is of limited originality: They hold that Kant adopted the position of Christian Wolff, the dominant figure in pre-Kantian German philosophy, by understanding state consciousness in terms of differentiation, that is, the distinction of different states from one another. ${ }^{1}$ I will instead make a case for an alternative interpretation, on which Kant's view is of considerable interest, novelty, and systematic importance.

The alternative interpretation I propose reads Kantian state consciousness as consisting in sensation. Consciousness is a specific qualitative feature, an inner

1. See Rosefeldt (2000: 213), Wunderlich (2005), Sturm and Wunderlich (2010), Dyck (2011).

Contact: Jonas Jervell Indregard <jonas.indregard@yahoo.com> 
sensation, that accompanies our representations to a greater or lesser degree, given in inner sense as a result of self-affection. This places Kant's view closer to the main German opponent of the Wolffians, namely Christian August Crusius: Crusius argued that consciousness is inner sensation, and proposed, in nuce, a theory of self-affection as the origin of these sensations. His theory thus constitutes a hitherto underappreciated precursor to Kant's account of inner sense.

This interpretation of Kantian state consciousness sheds light on some central topics in his theoretical philosophy, particularly the doctrine of self-affection. Kant's account of affection has faced a well-known and hitherto unsolved puzzle: If affection results in sensation (A19/B34), how can self-affection be a kind of affection, since (according to previous interpretations) there are no specifically inner sensations? ${ }^{2}$ Reading state consciousness as specifically inner sensation resolves this problem, and also elucidates the important role of self-affection in the $\mathrm{KrV}^{\prime} \mathrm{s}$ Transcendental Deduction, in particular the way in which self-affection makes perception, that is, empirical consciousness of appearances, possible (see B160, A120). ${ }^{3}$

Furthermore, the interpretation provides an important supplement to recent gains in our understanding of Kant's empirical psychology. ${ }^{4}$ Consciousness as inner sensation constitutes part of the neglected material side of inner intuition, allowing for novel interpretations of several psychological phenomena discussed by Kant: attention as an example of self-affection (see B156-157 Footnote); inner realities (mental powers) and our cognition of them; and the passive perception of our own thinking in inner sense, that is, a kind of Kantian cognitive phenomenology. These results enrich Kant's empirical psychology, but also bring it more in line with his views of intuition and experience in general.

\section{Wolff and Crusius on Consciousness}

Kant's account of state consciousness does not come in the form of an explicitly presented theory. In piecing together an interpretation from his various interspersed remarks, some background knowledge of the accounts prevalent in Kant's time will be helpful, and this section presents what I take to be the two main competing strands: The Leibnizian approach, represented by Christian Wolff; and the Thomasian-Pietist approach, represented by Christian August Crusius.

2. See Paton (1936/1976), Collins (1999), Allison (2004), Schmitz (2015).

3. References to Kant's works give Kant (1900-) volume and page, except the Kritik der reinen Vernunft where I use the standard A/B edition pagination. Translations are from Kant (1992-), or, where unavailable, my own. Abbreviations are indicated in a section at the end of the paper.

4. Frierson's (2014) otherwise comprehensive book on Kant's empirical psychology contains no explicit discussion of empirical consciousness. 
Several recent studies argue that Kant's account of consciousness must be understood in light of the then-dominant influence of Christian Wolff's Leibnizian theory. ${ }^{5}$ Wolff holds that we are conscious of something, whether of a thing or a representation, insofar as we differentiate [unterscheiden] it from something else (Wolff 1751: \$729). ${ }^{6}$ It is thus not possible to be conscious of something in isolation, without also being conscious of something else from which you differentiate it; differentiating them from one another results in being conscious of both. ${ }^{7}$ A conscious representation is clear; if one is also conscious of its parts the representation is clear and distinct. Wolff calls the act of differentiating "apperception" (1738: $\S \S 25,48),{ }^{8}$ and the resulting complex perception consisting of the conscious first-order perception and the second-order apperception a "thought" (1751: §194). Commentators have tended to read the required differentiation as intellectual, involving judgment. 9 In contemporary terms, Wolff thus proposes a kind of Higher-Order Thought theory of consciousness. ${ }^{10}$

Wolff faced opposition from the Thomasian-Pietist tradition to which Crusius belongs, among other things on the question of the nature of consciousness. ${ }^{11}$ According to Crusius, differentiation presupposes consciousness, rather than being equivalent to or resulting in it: "Consciousness is prior to differentiation according to the order of nature" (1745: §444; see similarly Rüdiger 1727: 4). If differentiation involves explicit judgment, the point is easy to grasp: To make the judgment " $\mathrm{A}$ is different from $\mathrm{B}$," one must according to Crusius already be conscious of A and B themselves. ${ }^{12}$

5. See Wunderlich (2005), Sturm and Wunderlich (2010), Thiel (2011), Dyck (2011).

6. Wolff here speaks of differentiating "things" [Dinge]; his later Latin works propose an equivalent definition for being conscious of a "perception" [perceptio] (1740: §10). Wolff uses "perception" more or less in the general sense of any mental item, Kant will later use "representation" (Vorstellung) with a similar meaning.

7. Several of the specifics of Wolff's account are unclear. While some read Wolff as holding that consciousness requires merely the ability to differentiate (Grau 1916: 187-188), Wolff's texts indicate that actual differentiation is required. His view on the nature of consciousness, and the exact relation between consciousness and differentiation-whether consciousness simply is the differentiation of one representation from another, or rather results from the differentiation - is difficult to ascertain precisely: Schulting (2015: 98) points out that Wolff claims that differentiation "grounds" consciousness (Wolff 1751: \$732), indicating the latter view; Dyck similarly refers to "the Wolffian claim of the priority of thought (as involving differentiation) to consciousness (that, namely, consciousness is the product of differentiation)" (2014: 180 Footnote).

8. See further Wunderlich (2005: 26).

9. In Wolff's own time, Andreas Rüdiger (1727: 14) and Dieterich Tiedemann (1777: 53f.) understood such differentiation to require judgment; see further Schepers (1959: 53) and Wunderlich (2005: 42f.).

10. See Thiel (2011: 305f.), Sturm and Wunderlich (2010: 56).

11. For analyses of Crusius's criticism of Wolff and his conception of consciousness, see also Wunderlich (2005: 43-45), Thiel (2011: 347-349).

12. This appeals to what we would now call access consciousness (see Block 1995), though the distinction between access and phenomenal consciousness is not made explicit in the $18^{\text {th }}$-Century 
Crusius instead links consciousness to our sensible faculties, essentially distinct from our intellectual capacities. While consciousness had been understood as sensation already in the Cartesian tradition, for example, by Malebranche, they understood "sensation" as confused representation (as opposed to thoughts, which are distinct), and consciousness as confused self-representation. ${ }^{13}$ Crusius, on the other hand, countenances "distinct sensation" (1747: $\S \S 435,436)$, and instead understands sensation as stemming from fundamental passive powers of the mind (cf. Crusius 1747: §86). ${ }^{14}$ Foreshadowing Kant's account of the distinct and complementary cognitive roles of understanding and sensibility, Crusius gives sensation, as a passively received state of mind, a crucial epistemic role: as representation through which the actual existence [Wirklichkeit] of something is immediately, non-inferentially given (1745: §16; 1747: §64, §434; compare Kant, A218/B266; KU 5:189).

For Crusius, this passivity does not exclude activity: the mind's power of sensation is an "active power" and sensations are "activities" (1747: §86). They nonetheless involve passivity insofar as "the soul, however, is passively determined to generate them, i.e., the soul is determined thereto by something which is distinct from the active fundamental power" (Crusius 1747: §86), and are thus simultaneously active and passive (see 1745: §66; 1747: §86; see further Dyck 2016). ${ }^{15}$ Unlike in the Wolffian tradition, however, passivity for Crusius involves a real influence (rather than the merely ideal influence of pre-established harmony) on the power of sensation whereby the nature of its activity is determined by a different power.

German context. Note that Crusius admits a weaker sense of 'differentiation' (see 1745: §444), where it simply means that two representations lead to different effects because they are different. However, while differentiation in this sense does not presuppose consciousness, it need not involve or result in consciousness either. For Leibnizian reasons, Wolff must concede this point: Different unconscious representations (e.g., different petites perceptions) can have different effects without thereby being or becoming conscious.

13. See Malebranche (1678/1997: 236-239); see further Grau (1916: 47f.) and Schmaltz (1996). A trace of this Malebranchian idea may be found in Baumgarten, who understands sensitive representations as those that are not distinct (1757/2013: \$521), and states: "Sensation is either INTERNAL SENSATION, and actualized through an internal sense (consciousness, more strictly considered), or EXTERNAL SENSATION, and actualized through an external sense" (1757/2013: §535). As far as I am aware it is not found in Wolff.

14. See already Thomasius (1691: Book 3, §\$35-36); see further Schepers (1959: 51-52). This disagreement thus intersects with another, more famous debate: Wolff and the Wolffians held that the soul can only have one power, whereas Pietists argued for several fundamental powers.

15. Kant affirms something close to this Crusian conception of passivity: "All passivity [Leiden] is nothing more than the determination of the power of the suffering [leidende] substance by an outer power" (MMr 29:823), where the power of the suffering substance is also active: "The substance being acted upon $\langle$ substantia patiens $\rangle$ is acting in itself $\langle e o$ ipso agens $\rangle$, for the accident would not inhere if the substance had no power through which it inhered in it, hence it also acts" (MMr 29:823). See further Wuerth (2014: Chapter 3), Indregard (2017b: 632-634). 
Crusius claims that consciousness "happens through inner sensation [innerliche Empfindung]" (1747: §93, cf. §§65, 85; 1745: §16; 1749: §§496, 498; 1767: \$335). More specifically, Crusius understands sensations as intentional states, and inner sensations as intentional states whose objects are the first-order mental states of which we are thereby consciously aware:

Through consciousness we have a representation of our thoughts themselves .... As the sun is the object of the idea of the sun: So the idea of the sun is, in consciousness, again the object of an idea, through which it itself is represented. (1745: §444; see 1747: §437)

Crusius thus proposes a Higher-Order Perception theory of consciousness along the lines of, for example, the "internal monitoring" theory of Lycan (1995), where some (but not all) our representations have second-order states directed at them in this manner and are thereby conscious. ${ }^{16}$ The way I understand Crusius's view, part of the import of conceiving consciousness in terms of inner sensation rather than second-order thought is the following: the idea of the sun is an object "in consciousness" because consciousness is the sensible quality through which the object (the first-order mental state) is immediately represented-as one could say that the sun itself is immediately represented "in sight" through sensible visual qualities, so the idea of the sun is immediately represented through the sensible quality of consciousness.

For Crusius, inner sensation denotes not only a particular kind of act or representation, but also the power (Kraft) responsible for such acts and representations. ${ }^{17}$ We find it characterized as the power of consciousness (Crusius 1745: §444; 1747: §65), and as a "fundamental power [Grundkraft]" (Crusius 1745: \$444; 1767: \$335). Perhaps surprisingly, Crusius also states at one point that he is unsure whether inner sensation "is a single fundamental power, or more, and if so how many" (1747: §84). However, the explication that follows indicates both how inner sensation fits the account of passivity noted above, and why at least two distinct powers (though perhaps not both fundamental) must be involved in the production of inner sensations. Crusius tells us first that outer sensation is produced if one is passively determined by a power outside oneself, and then states:

16. Indeed, he is a clearer representative of HOP theory than Locke, who sees consciousness as an essential aspect of all thinking and representation (see, e.g., Locke 1694/1975: II.xxvii.9); commentators disagree on whether he nonetheless equates it with second-order reflection produced through inner sense, which seems to invite an infinite regress problem (for discussion see Thiel 2011: 10gf.).

17. Crusius uses Empfindung (sensation) for a range of closely related concepts that he at one point distinguishes in Latin: "The representation arising from sensation one calls Sensationem, the act itself Sensionem, the power Sensum, and the tool of sensation, if there is one, Organon sensorium" (1747: §64). Context normally disambiguates which sense he has in mind. 
In a finite spirit, it is moreover possible that an active power is passively determined to a certain activity by another active power of the same subject, and this is the case for inner sensation. (1747: §86)

When it comes to inner sensation, another active power within the same subject is responsible for determining the power of inner sensation. As far as I am aware, Crusius never specifies which other power this may be. The structure of internal influence that he suggests here, however, fits Kant's theory of self-affection as the "influence of the understanding on the inner sense" (B154). In what follows I will suggest that Kant's view specifically resembles and builds on Crusius's in this respect: conceiving state consciousness as inner sensation that results from self-affection.

\section{Against the Wolffian Reading of Kant}

Kant's account of consciousness has been the subject of several recent studies. ${ }^{18}$ However, the proposal that the mature Kant understood state consciousness in Crusian terms, as inner sensation, is novel. ${ }^{19}$ Before arguing for this proposal, an important complication in studying Kant's account should be noted:

Wolff and Crusius each operate with a single notion of consciousness roughly corresponding to what we now call state consciousness. Kant, in his Critical period, distinguishes the "psychological," "intuitive," or "empirical" consciousness given through inner sense from the "logical," "discursive," or "pure" consciousness of transcendental apperception..$^{20}$ The latter is of vital importance to Kant, but more plausibly construed as a kind of act-consciousness, ${ }^{21}$ or as a special kind of self-consciousness, ${ }^{22}$ than as state consciousness. Transcendental apperception as such is often contrasted with the consciousness of specific mental states:

18. See Wunderlich (2005), La Rocca (2008), Serck-Hanssen (2009), Sturm and Wunderlich (2010), and Schulting (2012b; 2015).

19. Wunderlich points to some of the passages I will discuss in this section, and suggests that Kant's "Ausführung wären allerdings nicht nur mit der wolffianischen Erklärung, sondern auch mit der von Rüdiger und Crusius, wonach Unterscheiden Bewußtsein voraussetzt, vereinbar" (Wunderlich 2005: 141). However, he does not pursue this suggestion.

20. For the distinction between psychological and logical consciousness, see $M L_{1}$ 28:227; Anth 7:142; between intuitive and discursive consciousness, see Anth 7:141; between empirical and pure or transcendental consciousness, see A117 Footnote, B207-208; Anth 7:141-142; R6311 18:610-611. Kant distinguishes two faculties, inner sense and apperception, one for each of these kinds of consciousness; see A107, B152; Anth 7:141-142, 7:161; MMr 29:882.

21. See B133, B153, B157-158 Footnote, B423 Footnote; Anth 7:141-142. See further Watkins (2005: 274f.), Serck-Hanssen (2009), Kitcher (2011).

22. See A117 Footnote, B68, B132, B157-158. See further Brook (1994), Wuerth (2014). 
Inner sense is the consciousness of our representations themselves .... If the soul is conscious of itself to itself, without being conscious of its state, this is apperception. If it is also conscious of its state, then it is sensation or perception. (MMr 29:882; see also A107) ${ }^{23}$

\section{This article thus focuses on empirical consciousness. ${ }^{24}$}

Kant considers inner sense to be the medium of state consciousness, and the states of which one are conscious as given in inner intuition. A Wolffian account may understand this as referring to the material, that is, the mental states that are differentiated, as intuitive and temporally located (see Wunderlich 2005: 159f.). It may perhaps also allow that sensory differentiation can occur without discursive thought (though against some proponents of the Wolffian account, the position can then no longer plausibly be characterized as a Higher-Order Thought theory). ${ }^{25}$ However, analysis of some central passages, in this section and the next, suggest instead a Crusian reading as a fruitful interpretational alternative. An important footnote in the $\mathrm{KrV}$ provides the most perspicuous entry point:

Clarity is not, as the logicians say, the consciousness of a representation; for a certain degree of consciousness, which, however, is not sufficient for memory, must be met with even in some obscure representations, because without any consciousness we would make no distinction [Unterschied] in the combination of obscure representations; yet we are capable of doing this with the marks of some concepts (such as those of right and equity, or those of a musician who, when improvising, hits many notes at the same time). Rather, a representation is clear if the consciousness in it is sufficient for a consciousness of the difference [Bewußtsein des Unterschiedes] between it and others. To be sure, if this consciousness suffices

23. Kant's contrasting of inner sense with apperception here suggests that "apperception" refers to transcendental, rather than empirical, apperception (as in the similar contrast at B153). See further Wuerth (2014: 118f.).

24. Hence my argument in what follows is not directed against an interpretation of transcendental apperception along more Wolffian lines. Note that while empirical apperception (A107, B139; Anth 7:134 Footnote; MD 28:670), as empirical self-consciousness that includes consciousness of one's state, is intimately related to state consciousness, it is not my primary focus here-a full account of empirical apperception arguably depends on a prior grasp of both Kant's account of state consciousness and his account of transcendental apperception. Some indications of how state consciousness contributes to empirical self-consciousness and cognition is given in Section 8, below.

25. Relevant for a full development of the Wolffian reading(s) is Kant's theory of synthesis, and such questions as whether Kant can allow for pre-discursive synthesis, as well as whether, and if so how, such synthesis already involves, or allows for, differentiation. I cannot treat these difficult and complex issues here, and will focus instead on passages more directly concerned with state consciousness. 
for a distinction [Unterscheidung], but not for a consciousness of the difference [Bewußtsein des Unterschiedes], then the representation must still be called obscure. So there are infinitely many degrees of consciousness down to its vanishing. (B414-415 Footnote) ${ }^{26}$

Kant here rejects Wolff's identification of clarity and consciousness. ${ }^{27}$ How deep does this rejection go? Dyck's Wolffian reading of Kant proposes that "if Kant loosens Wolff's tie between consciousness and clarity, he does so on what are, at bottom, Wolffian grounds since obscure representations are taken to be conscious only inasmuch as they do permit of differentiating among them" (Dyck 2011: 47). While it is true that Kant's argument for conscious but obscure representations proceeds from the fact that some obscure representations can be differentiated, a closer look at the passage nonetheless reveals several indications of a Crusian position where differentiation presupposes consciousness. First, Kant claims that "without any consciousness we would make no distinction," a phrasing which is more natural if consciousness a condition of distinction-making rather than vice versa, as a metaphysics lecture states explicitly: "Consciousness ... is the ground of the differentiation [Unterscheidung] of one thing from another" (MVo 28:425, my italics).

Second, Kant emphasizes the need for "sufficient" (zureichend) consciousness, by considering "if this consciousness suffices for a distinction [Unterscheidung]" (B415 Footnote, my emphasis) at all. This implies the possibility of a consciousness that is insufficient for distinction-making tout court; the question of sufficiency requires the contrasting possibility of insufficient (unzureichend) consciousness. ${ }^{28} \mathrm{~A}$ Wolffian account where consciousness is equivalent to or the product of differentiation cannot countenance consciousness that is insufficient for making distinctions at all. ${ }^{29}$ On Kant's account, however, differentiation re-

26. Here Kant speaks only of obscure concepts. The Anthropology uses the same example of an improvising musician to indicate obscurity in the "sensations of hearing" (Anth 7:136).

27. Confusingly, some of Kant's logic lectures affirm the identification of clarity with consciousness (e.g., JL 9:33). However, I take it that Kant's repudiation of what "the logicians say" here would include his own logic lecturing over Wolffian textbooks, and signals his considered view.

28. See similarly: "Consciousness of one's representations that suffices for the differentiation of one object from another is clarity" (Anth 7:137-138). Dyck reads this as support for the claim that "for Kant, as for Wolff, consciousness is understood in terms of differentiation, and assigned a degree depending on the extent to which we differentiate our representations" (Dyck 2011: 46; see similarly Rosefeldt 2000: 213), but here as well the possibility of consciousness that is insufficient for differentiation seems implied.

29. One may respond that the sufficiency in question only concerns a specific kind of distinction-making, e.g., with regards to the marks of a specific concept. Consciousness could still be equivalent to or the product of some other act of differentiation (I thank a referee for this suggestion). However, that still undermines the Wolffian reading of this passage itself (since consciousness is then distinct from and prior to the kind of differentiation discussed here), and sets the 
quires a sufficient degree of consciousness. This fits Kant's presentation of the "degrees of cognition" in $J L$, where "to represent something with consciousness" (JL 9:64) is the second degree of cognition, whereas "to be acquainted with [kennen] something (noscere), or to represent something in comparison to other things, both as to sameness and as to difference" (JL 9:65) is the third degree. Differentiation characterizes kennen and hence involves something different than mere representing with consciousness (see also R2394 16:342-344). ${ }^{30}$

Third, the possibility of an insufficient degree of consciousness is made evident in the footnote's final sentence: "So there are infinitely many degrees of consciousness down to its vanishing" (B415 Footnote). In the main text, Kant states that "consciousness always has a degree, which can always be diminished" (B414), and elsewhere, he claims that "between consciousness and total unconsciousness (psychological obscurity) ever smaller degrees occur" (Prol 4:306-307, translation modified; see $M M r$ 29:834; MVi 29:1000). Differentiation presumably does not admit of infinite and ever smaller degrees. ${ }^{31}$ A Wolffian account will instead operate with a minimum, a degree of consciousness that only barely suffices for differentiation, below which representations are completely unconscious. Baumgarten calls this the "minimally clear," beyond which there are no ever smaller degrees but only the "most obscure perception" which can be distinguished from nothing:

challenging task of finding textual evidence elsewhere for the connection between consciousness and this other kind of differentiation.

30. The picture is complicated by the fact that Kant, like Crusius, acknowledges two different kinds of differentiation. One, of which animals is capable and which he calls "physical differentiation" in one of his early works (FS 2:59-60), does not require consciousness at all but simply that one is "driven to different actions by means of different representations" (FS 2:59). The other, of which animals are not capable and which he calls "logical differentiation," does require consciousness, of a sufficient degree (at this pre-Critical stage Kant holds that it also requires judgment, although in his Critical period he may think that conscious differentiation can be had on an intuitive level without applying concepts in judgment, e.g., the "savage" in JL 9:33).

31. I say presumably because while, e.g., Baumgarten's account explicitly operates with a minimum, Kant never endorses this account. It is thus possible to claim that Kant instead thinks of differentiation as allowing for ever smaller degrees. It is however not so easy to see how it would work: A plausible case could be made that differentiation, on Kant's account, could take ever greater degrees, since there are no lowest species, and something can therefore always be further conceptually specified and differentiated (A655-656/B683-684; JL 9:97). There are, however, highest concepts, "from which, as such, nothing further may be abstracted without the whole concept disappearing" (JL 9:97). The minimum of differentiation for Kant, then, is something like the point at which one is able to make only a single distinction within such a highest concept (perhaps only that it is something rather than nothing; see Kant's conception of an "object in general" as the highest concept at A290/B346f.). Ever smaller degrees could perhaps instead pertain, e.g., to the everincreasing difficulty of differentiating (I thank an anonymous referee for this suggestion)-while possible, I know of no textual evidence suggesting that this would be Kant's view, and I think the passages presented in Section 4 below instead point to Kant's account of degrees of sensation.

Ergo •vol. 5, no. $7 \cdot 2018$ 
The perception whose notes are only sufficient for distinguishing it with the greatest difficulty from the one most different thing is minimally clear ... . The most obscure perception for me ... is that which can be distinguished from nothing, even the maximally different, with all of my power being employed. (1757/2013: §528) ${ }^{32}$

The contrast between Baumgarten's account and Kant's "ever smaller" degrees of consciousness is evident. Kant's phrasing, as we shall now see, instead points towards his theory of sensation.

\section{Consciousness as Sensation}

Investigating Kant's reason for admitting ever smaller degrees of consciousness takes us towards the part of Kant's philosophy concerned with the sensory qualities of representations and objects:

Between every given degree of light and darkness, every degree of warmth and the completely cold, every degree of heaviness and absolute lightness, every degree of the filling of space and completely empty space, ever smaller degrees can be thought, just as between consciousness and total unconsciousness (psychological obscurity) ever smaller degrees occur; therefore no perception is possible that would show a complete absence, e.g., no psychological obscurity is possible that could not be regarded as a consciousness that is merely outweighed by another, stronger one, and thus it is in all cases of sensation. (Prol 4:306-307)

Ever smaller degrees of consciousness can occur because "thus it is in all cases of sensation" (Prol 4:307). An a priori principle concerning sensation explains why, namely the principle explicated in $K r V^{\prime}$ s Anticipations of Perception (to which this part of the Prolegomena corresponds). Intensive magnitude, that is, degree, is ascribed to the perceptual component of our cognition; to sensations, and to the realities corresponding to these sensations in objects: "In all appearances the sensation, and the real, which corresponds to it in the object (realitas phaenomenon), has an intensive magnitude, i.e., a degree" (A165).33 And here we find that "every sensation ... , however small it may be, has a degree, i.e., an intensive

32. The same account of the 'completely obscure' as that which is not differentiated from anything else is found in Wolff (1738: §46) and Meier (1752: §13, §125).

33. The principle in the B Edition refers only to the real in the object, not to the sensation (B207). However, in the Proof at B208 Kant still asserts that the sensation, as well as the real corresponding to it, has an intensive magnitude. 
magnitude, which can still always be diminished ..., which, however small it may be, is never the smallest" (A169/B211). Tellingly, the Anticipations themselves also speak of consciousness as having a degree (B208, A176/B217-218).

Another passage from Prolegomena also refers to "consciousness in general," alongside pain, as examples of inner representations that have an intensive but not an extensive magnitude:

Warmth, light, etc. are just as great (according to degree) in a small space as in a large one; just as the inner representations (pain, consciousness in general) are not smaller according to degree whether they last a short or a long time. (Prol 4:309 Footnote)

I read both these Prolegomena passages as referring to consciousness as sensation, an inner representation with an intensive magnitude. Admittedly, they both stop short of explicitly stating so. However, why Kant would refer to consciousness as having a continuously diminishable degree, in this context, unless he took consciousness to be an example of what he is discussing: Sensations and their corresponding realities, to which the a priori principle of the Anticipations ascribes a degree? A continuously diminishable degree of consciousness is hardly something he could independently appeal to as an agreed-upon fact, regardless of one's theory; as we have seen, not all Wolffian theories regard consciousness as continuously diminishable.

This leaves open the possibility that consciousness is a reality rather than a sensation. The relation between sensation and reality with respect to consciousness will be considered further below; for now, I will note that Kant refers to consciousness as "inner representation" (Prol 4:309 Footnote) and further that the context of the B414-415 footnote considered above also seems to place consciousness in the position of sensation rather than reality: Kant discusses a purported proof of the immortality of the soul found in Moses Mendelssohn's Phaedo. Mendelssohn argues that there is no natural way for the soul to perish if (as Kant grants) it has no parts, and hence that the soul is immortal. Kant replies that even if it has no parts,

one nevertheless cannot deny to [the soul], any more than to any other existence, an intensive magnitude, i.e., a degree of reality in regard to all its faculties .... For even consciousness has a degree, which can always be diminished; consequently, so does the faculty of being conscious of oneself, and likewise with all other faculties. $\left(B_{414}-415\right)^{34}$

34. Variations of this argument can also be found at MAN 4:542; MMr 29:905-906, 29:912-913; $M K_{2}$ 28:761, 28:763-764; MVi 29:1037; R5650 18:299. 
Here, it seems natural to read consciousness as sensation having a diminishable degree, so that "consequently" the corresponding faculty has a degree of reality that can also be diminished.

I have presented several reasons for doubting the Wolffian interpretation of Kant's account of consciousness, and textual evidence suggesting that Kant may instead have held a Crusian account of consciousness as sensation. While the considerations advanced certainly stop short of refuting the Wolffian interpretation of consciousness, they give reason for considering the implications of the alternative Crusian interpretation within Kant's overall framework. Indeed, the proper conclusion to draw so far may be that the Wolffian conception of consciousness in terms of differentiation is not the full story: that a Crusian understanding of consciousness as inner sensation is plausibly, if not the only then at least also part of Kant's position. Much of what I will go on to discuss concerning inner sensation and self-affection could perhaps be adopted by a reading that remained, in some suitably modified sense, Wolffian, by understanding it as explicating the sensory result of differentiation. In what follows I will disregard this complication and focus on developing what I take to be the specifically Crusian aspect of Kant's theory.

\section{Consciousness and Self-Affection}

Kant's and Crusius's accounts of sensation, and thus also of state consciousness, are not identical. Unlike Crusius, Kant does not conceive of sensation as intentional (see $\mathrm{B}_{207}, \mathrm{~A}_{\left.320 / \mathrm{B}_{376}\right) .35}$ As a result, his view is arguably not higherorder, at least in the standard sense. ${ }^{36}$ State consciousness, for Kant, is not a second-order representation, but something that "accompanies different representations" (B133) and constitutes added sensory content to the first-order state. Nonetheless their accounts, on my interpretation, share crucial features: First, they conceive of state consciousness as a specific kind of inner sensation, just like color, sound, etc., are specific kinds of outer sensation. How is this to be understood? As a first sketch, without delving into controversial matters concerning Kant's philosophy of perception, I suggest the following: Empirical intuitions contain sensations as their matter, and these sensations have a 'phenomenal quality' and a degree of intensity. Whereas outer empirical intuitions contain,

35. This is not to deny that there is a sense in which sensation, for Kant, involves intentionality. While sensations as such are not intentional (in the sense of representing an object), they do play a crucial role in representing objects (by constituting the matter of intuition). For further discussion of these issues, see Jankowiak (2014).

36. His view is closer to the "Dual Content" theory of Carruthers (2000) or the "Second Sense" theory of Droege (2003). 
for example, visual and auditory sensations with qualities like color, timbre, and so on, inner empirical intuitions contain inner sensation with the phenomenal quality of being conscious to a greater or lesser degree. In other words, the point is not that all sensations are conscious but rather that consciousness is a specific kind of sensation. Second, Kant and Crusius understand the cause of such inner sensations to lie in the activity of another, different power within the mind, affecting the inner sense and thereby producing sensations. In what follows I will try to explicate these points - state consciousness as specifically inner sensation and as a result of self-affection-more fully.

Crusius explicitly contrasts outer and inner sensation and aligns consciousness with the latter. Kant, unfortunately, is less explicit. One could instead read him as holding that any sensation constitutes consciousness, or alternatively that any sensation, when apprehended, constitutes consciousness. ${ }^{37}$ Kant does characterize state consciousness as "psychological" (Prol 4:306-307), as "inner representation" of a kind with pain (Prol 4:309 Footnote), and as related specifically to inner experience: "Inner experience contains the material of consciousness and a manifold of empirical inner intuition" (Anth 7:141-142). But these points are not decisive, and there are also passages that seem to favor reading all apprehended sensations as constituting consciousness (see, e.g., A176/B217). However, broader systematic considerations speak strongly in favor of reading consciousness as specifically inner sensation. The three following sections, 6-8, will consider three important issues: Attention, Generality, and Self-Relation. The remainder of this section presents the more fundamental upshot of the Crusian reading from which the specific issues emerge, namely integrating Kant's account of empirical state consciousness with his doctrine of self-affection.

Most interpreters till now have held that there is no equivalent of outer sensation given in inner sense. This leads to a deep worry concerning Kant's theory of self-affection, namely whether it is properly characterized as affection at all: "How can something be called affection if no new sensation is produced?" (Schmitz 2015: 1052; see Allison 2004: 282-283). ${ }^{38}$ This is concerning in light of Kant's initial definition of sensation in the Transcendental Aesthetic: "The effect of an object on the capacity for representation, insofar as we are affected by it, is sensation" (A19-20/B34). One could try to avoid the problem by point-

37. Schulting advocates an interpretation along these lines: "In apprehending the sensation at a particular point in time ..., an empirical consciousness of a certain degree of intensity is apprehended" (2012a: 163; see 2012b: 291).

38. See also Nabert (1924), Paton (1936/1976: 388-389), Collins (1999: 113-114), Gardner (1999: 299-300). Some commentators admit subjective but not objective inner sensations (for this distinction, see $K U$ §3). Jankowiak (2014), for instance, defines objective sensation as "sensations which contribute to the cognition of the (external) object" (Jankowiak 2014: 500, my italics; see similarly Hanna 2013: 194). The only commentator I know of that explicitly affirms objective inner sensation is Kraus (2016), though her interpretation differs greatly from mine. 
ing out that sensation is said to be the effect of an object affecting us, whereas self-affection instead involves the subject. ${ }^{39}$ However, this is difficult to reconcile with the text, since Kant emphasizes that through self-affection in inner sense "the subject, which is the object of this sense, can only be represented by its means as appearance" (B68, my italics; see B155-156). If inner sensations are lacking, it is difficult to see how one can have empirical inner intuitions, given Kant's definitions: "That intuition which is related to the object through sensation is called empirical. The undetermined object of an empirical intuition is called appearance" (A20/B34). By arguing that there is an equivalent of outer sensation given in inner sense, namely state consciousness, the Crusian reading ensures that these worries gain no traction. This enables empirical inner intuition to fit Kant's general characterization of empirical intuition: having not just a specific form (time), but also a specific matter, the "material of consciousness" (Anth 7:141). The existence of the empirical subject may thereby be cognized in conformity with Kant's account of actuality, as "that which is connected with the material conditions of experience (of sensation)" (A218/B266) (see further Section 8 below).

Furthermore, the reading explains how self-affection makes "perception, i.e., empirical consciousness of [an empirical intuition] (as appearance)" (B160) possible. Some recent readings of the Deduction have emphasized that Kant specifically points to perception, that is, intuition with empirical consciousness (A119-120), as requiring synthesis in accordance with the categories (see Tolley 2013 and in press; Matherne 2015). Whether or not one this leaves room (as Tolley argues) for fully non-conceptual intuitions, it seems crucial to understand more precisely that which distinguishes perception from mere intuition, namely (empirical) consciousness. Importantly, Kant often indicates that perceptionsdespite requiring synthesis - are intuitive representations, given in sensibility and not themselves composed of concepts or judgments (see, e.g., A86/B118-119, A115; Anth 7:128; N, 23:28). The Crusian reading can explain perception in accordance with these specifications: Perception is intuition accompanied by inner sensation (i.e., state consciousness), a fully sensible representation which nonetheless requires synthesis-since inner sensation is generated through selfaffection by the synthetic activity of the understanding, whereby inner sense becomes what Crusius describes as "passively determined to a certain activity

39. Although none of them propose this explicitly as a solution to the worry concerning the relation between affection and sensation, I believe both Allison and Schmitz would find this response appealing: Allison holds that "although Kant frequently characterizes the [object of inner sense] in traditional terms as the soul, mind, or self, no such object is encountered in inner experience" (2004: 278), while Schmitz states that "I recommend attributing the position to Kant that there are no inner intuitions - i.e., no intuitions of inner objects of any kind" (2015: 1057). 
by another active power of the same subject" (1747: $\$ 86) .4^{40}$ This is not to say that self-affection's sole function is to generate inner sensations - there is also an essential formal aspect to self-affection involved in our representation of space and time. ${ }^{41}$ However, explaining the role of self-affection in generating perception also requires an understanding of its material dimension in producing empirical consciousness. To specify how this generation takes place I turn now to Kant's account of attention.

\section{Attention}

Attention is characterized by Kant as the "endeavor to become conscious of one's representations" (Anth 7:131), and is hence relevant to his account of state consciousness. Considering attention provides further reason for thinking that state consciousness is a specifically inner sensation:

Imagine looking at a painting hanging on a wall. Initially, you regard the painting inattentively, since you're busy trying to think through and evaluate the argumentative steps of Kant's Transcendental Deduction. At some point you give up, and instead start paying attention to the painting. You begin to notice details of the scenery depicted in the painting, peculiarities of color and brushstroke, etc. You become conscious of them, or, perhaps better, the degree to which you are conscious of them increases. Plausibly, the phenomenological character of your perception changes. This requires no outer alterations-whether in lighting conditions, the direction of your gaze, the acuteness of your sight, or any other change. Your consciousness of the painting can change without either the painting itself or your outer senses changing. In other words (or so it would seem) the change of consciousness is not primarily a change in outer sensations..$^{42}$ Attention can make you acutely conscious of intuitions accompanied by only

40. Why are perceptions, i.e., intuitions with state consciousness, needed for the further cognitive processing leading to "experience [as] cognition through connected perceptions" (B161)? Plausibly, many of the functions of our higher powers required for experience demand conscious representations, in particular for the voluntary and normatively regulated execution of those functions; the Jäsche Logik states that "since consciousness is the essential condition of all logical form of cognitions, logic can and may occupy itself with clear but not with obscure representations" (JL 9:33). A further investigation of these complex issues must be undertaken elsewhere.

41. I do not think the relation between affection and sensation stated at A19-20/B34 implies that sensation must be the only effect produced by affection. For more on the formal aspect of selfaffection see Schmitz (2015), Indregard (2017b).

42. This is not to say that attention has no effect on outer sensations-it may well be the case that, e.g., a visual patch attended to seems relatively bigger and more saturated (see Carrasco, Ling, and Read 2004 for experimental evidence, and Block 2010 for discussion). For a detailed contemporary argument that the phenomenal contribution of attention is not exhausted by its effect on outer appearances (outer intuitions in the Kantian sense), see Watzl (2017: ch. 8). 
the subtlest and weakest of outer sensations (someone whispering a piece of crucial information to you), while lack of attention can allow intuitions accompanied by the strongest and most vivacious outer sensations pass by nearly without consciousness (construction work outside your office while you are lost in thought). 43

The Crusian account is perfectly placed to explain such sensible variations in the absence of outer alteration, by pointing to changes in degree of consciousness as changes in specifically inner sensation. ${ }^{44}$ Some representations may have strong outer sensations but weak inner sensations, and vice versa. Inner sensations are not directly caused by the activity of outer objects, but by actions of the mind, that is, by self-affection, and these inner actions can vary independently of outer affection and sensation. This also fits Kant's use of attention as a prime example of self-affection (B156-157 Footnote; FM 20:270; R6354 18:680). If attention is an action of the mind causing (stronger) consciousness-sensations, we see how the "endeavor to become conscious of one's representations" (Anth 7:131) is an example of self-affection. ${ }^{45}$ Moreover, the claim that representations have a "degree of consciousness ... corresponding to the amount of attention directed to them" (EE 20:227 Footnote) can, as we shall see (in Section 8), be understood in terms of the correspondence between the consciousness-sensation and the degree of reality of the mind's power of attention.

\section{Generality}

A further point against conceiving consciousness as constituted by (apprehended) outer sensations is that outer sensations cannot account for the full range of contexts in which Kant holds that representations have a degree of consciousness. We are (more or less) conscious not just of outer intuitions, but also for instance of concepts. The strength of outer sensations such as colors, sounds, feels, etc., cannot explain the degree of consciousness accompanying the concepts of "right" and "equity" and their marks (B414-415 Footnote; see EE 20:227 Footnote). ${ }^{46}$ Intuitive and imaginative representations (involving outer sensation) might of course accompany, or be subsumed under, the concepts in question. But the relatively weak degree of consciousness we have of "right" and

43. Cf. the famously inattentive long-distance truck driver in Armstrong (1981: 723f.).

44. Note that the Wolffian reading can also explain this variation by pointing to changes in how one's representations are differentiated. My point here is merely that there is a change in phenomenological character that is irreducible to change in outer sensation.

45. Merritt and Valaris (2017) focus on the consequences of Kant's account of attention for the non-conceptualism debate; I take my characterization of the outcome of acts of attention and the nature of the consciousness involved to be compatible with their view.

46. Kriegel (2003) makes a similar point in the contemporary context. 
"equity" cannot be identified with a lack of vividness in the sensations accompanying, for example, examples of these concepts, or associated imagery. Kant's other example makes this point clearer: "A musician who, when improvising, hits many notes at the same time" (B415 Footnote) represents obscurely, and hence with a relatively small degree of consciousness. However, this is not something that she can remedy by playing more loudly.

Consciousness as inner sensation, on the other hand, can pertain not just to representations that contain outer sensation as an integral component. Kant's ascription of some degree of consciousness to all representations available to cognition (Prol 4:306-307) is thus of a piece with his repeated claim that all our representations belong to inner sense (A34/B50, A98-99, A101, A138/B177, A155/ B194, A177/B220, A197/B242; MS 6:214). This includes concepts, judgments, and inferences, qua modifications of the mind or mental occurrences (A358-359; FM 20:270; MSV 27:502-504; R6319 18:633, R5661 18:318-320). Here we see a consequence of the fundamental role Kant ascribes to self-affection of our inner sense for possible experience in general (see B151f.). Coupled with Kant's account of affection as resulting in sensation, this fundamental role suggests that there should be inner sensation produced in relation to all our intuition and experience. We see now that this is indeed the case: All our representations belong to inner sense and have a degree of consciousness, as the "effect of an object on the capacity for representation, insofar as we are affected by it" (A19-20/B34) - the object in question in this case being ourselves.

Passively perceiving one's own thinking in inner sense thus involves what we may describe as a cognitive phenomenology. 47 The phenomenal character of such thought is constituted not by outer sensations, but by inner sensations such as consciousness. ${ }^{4}$ Passively perceived discursive thought may include other additional phenomenal elements, including non-cognitive aspects (like feelings of pleasure or displeasure). ${ }^{49}$ But consciousness as inner sensation constitutes an important element of the specifically sensible component of "what [the human being] undergoes, in so far as he is affected by the play of his own thoughts" (Anth 7:161).50

47. The phenomenology is still in a broad sense sensory rather than cognitive, insofar as it originates in inner sense. However, in the contemporary context it resembles what is meant by cognitive phenomenology rather than sensory phenomenology.

48. Hanna similarly suggests that "Kantian cognitive phenomenology includes . . the difference between clarity and unclarity, and between distinctness and indistinctness" (2013: 194). However, he does not explicate how this inclusion should be accounted for within the Kantian framework, and does not countenance objective inner sensations (he distinguishes between "endogeneously-caused," i.e., inner, sensations as "subjective sensations" (CPJ 5:206) or "feelings," and "exogeneously-caused," i.e., outer, sensations as "'objective sensations,' such as the sensations that accompany the perception of external objects" (Hanna 2013: 194)).

49. See, e.g., KU 5:187. See further Merritt (2014).

50. Concerning the passive perception of one's thinking, see also Renz (2015).

$$
\text { Ergo } \cdot \text { vol. 5, no. } 7 \cdot 2018
$$




\section{Self-Relation}

Kant states that "even consciousness has a degree; consequently, so does the faculty of being conscious of oneself" (B415; see also MAN 4:542; MVi 29:1037). The "consequently" in this passage cannot be explained by outer sensations, which presumably correlate with the degrees of outer realities rather than the degree of reality of our inner faculties. Outer sensations might inform us of the degree of reality of our outer sensibility, its acuity or "determinate degree of receptivity for the sensations" (A172/B214), but do not provide any information concerning the degree of reality of "the faculty of being conscious of oneself" (B415) or the "faculty of consciousness, apperception" (MAN 4:542).

If consciousness is inner sensation, on the other hand, B414-415 reads as pointing to the connection between the degree of consciousness (as inner sensation), and the "degree of reality" (B414) of the "faculty of consciousness" as the realitas phaenomenon corresponding to this sensation. The correspondence indicated by "consequently" then follows from the Anticipations, where the degree of the sensation is said to correspond to the reality's "degree of influence on sense" (B208). ${ }^{11}$ In the case of consciousness, this is the "influence of the understanding on the inner sense" (B154) exercised by the "faculty of becoming conscious of oneself" (cf. B68).

We may also attribute acts of attention to this faculty (B156-157 Footnote), as Kant states that representations are accompanied by a degree of consciousness "corresponding to the amount of attention directed to them" (EE 20:227 Footnote; see also NG 2:190-191). Presumably, one's power to attend can vary from person to person and from time to time, depending on one's talents and condition, so that "the point of fatigue [Grade der Beschwerlichkeit]" (FM 20:270) depends on the strength of one's power. Cognizing the "degree of reality" of one's faculty of consciousness as realitas phaenomenon thus provides substantive information concerning the phaenomenon in question: the soul of an individual empirical subject, as object of inner sense..$^{2}$

Outer realities as causal powers can be in real opposition where they more or less cancel out their effects, as, for example, two attractive powers pulling a body in opposite directions may cancel each other out, leaving the body at rest. Kant envisages a similar possibility with respect to consciousness: acts of abstraction exert one's power in a way opposed to acts of attention (Anth 7:131-132; NG

51. Kraus instead argues that the real in inner sensation consists of those of our mental states that "cannot be changed at will, [e.g.], a feeling or desire merely occurs and cannot intentionally be induced or abandoned" (Kraus 2016: 342).

52. Further references to the soul as object of inner sense and inner experience can be found at, e.g., Bxxvii, A34/B50, B69, A342/B400, A385-386, B427, A683/B711, A846/B874; Prol 4:336-337; MAN 4:667, 4:771; KU 5:460-461. 
2:189-190). ${ }^{53}$ In many circumstances, abstraction and attention work together in tandem, since abstracting from some representations makes it easier to focus one's attention on those that remain; it is not difficult, however, to think of cases where they become really opposed - the attempt to disregard an annoying sound, or, in Kant's unfortunate example, a suitor's attempt to "overlook a wart on his beloved's face, or a gap between her teeth" (Anth 7:132).

In speaking of inner sensations and of the mental causal powers generating these sensations, I suggest a Kantian empirical psychology that goes beyond a "Humean bundle" theory of the empirical self (see Allison 2004; Dyck 2014; Wuerth 2014: Chapter 1). This is consonant with Kant's discussions of empirical psychology, where causal explanations involving the faculties or powers of the mind take center stage (see Frierson 2014). ${ }^{54}$ Is this empirical psychology consistent with Kant's ardent denial of any attempt to prove the substantiality of the soul (e.g., in the Paralogisms)? I cannot treat this difficult issue fully here; Frierson (2014: Chapter 1) suggests that we can legitimately treat the self as a substance in empirical psychology (see also Chignell 2009), but I think there is also evidence that we can legitimately treat the self as an object of inner sense with powers, even if we cannot show this object's substantiality:

Instead of the word 'soul', we have taken to using that of living power (and rightly so, since from an effect we can certainly infer to the power that produces it, but not forthwith to a substance specially adapted to this kind of effect). (FP 8:413, translation modified; see $M M r$ 29:772)

\section{Objections}

I now consider four objections to my interpretation of state consciousness in Kant. Answering these objections also allows me to further flesh out the account I have provided:

\subsection{The Quality of Consciousness.}

Sensations have not just an intensive magnitude, that is, a degree; they also have a quality, which can only be given a posteriori-we know a priori that any sensation has a degree, though not which degree (A175-176/B217-218). I have argued

53. Zinkin suggests that attention and abstraction are causal powers of the mind, and that "our consciousness of this activity is thus a kind of sensitivity rather than a kind of cognition" (2012: 411), a suggestion amicable to the interpretation I propose.

54. See Indregard (2017a) for an account of how mental powers figure in Kant's theory of empirical character. 
that the intensive magnitude of empirical consciousness is not reducible to the intensive magnitude of outer sensations. But if consciousness is a specific kind of inner sensation, it must also have its own specific kind of quality. Does it? If one considers different conscious representations, for example, a thought, a sensation of redness, an intuition of a black cloud, etc.: Are they all accompanied by the same kind of sensory quality, namely consciousness as inner sensation?55 One might instead suggest that consciousness as such is, as it were, transparent: ${ }^{56}$ Having a conscious representation, say of a tree, presents one with a range of sensory qualities like colors, smells, and so on, without the quality of consciousness itself being among them.

Explicit evidence is scarce, but Kant does sometimes indicate that he sees consciousness as a specific quality of its own: "Consciousness is a quality of my thinking and thus has a degree, for every quality always has a degree. My apperception, as we call our consciousness, thus has a quality of thinking" $\left(M L_{2}\right.$ 28:590; see also $M M r$ 29:834; MVi 29:1000). 57 Less exegetically, recent work within philosophy of mind has pushed back against the idea that there is no qualitative commonality to the widely different representations of which one is attentively conscious, namely something like a specific quality of 'presence to mind": "It is plausible that there is a phenomenal property that all attention episodes share. After all, it is natural to describe every phenomenal contribution of attention (partially) in terms of 'concentration of consciousness,' 'experiential highlighting,' or 'phenomenal salience'” (Watzl 2017: 165)..${ }^{8}$ I surmise that this would also seem plausible to philosophers in the early modern period, including Kant, supported by the qualitative vocabulary through which consciousness is characterized - in terms of obscurity

55. Contemporary critics of inner sense theories have found this implausible; see, e.g., Lyons (1986: 96), Rosenthal (1990: 34-35).

56. See Harman (1990). With respect to Kant, one might strengthen this suggestion by pointing to Kant's purported claim that "inner sense has no manifold of its own." I discuss this claim in Section 9.4 below.

57. I take it that in this passage, Kant is referring to empirical apperception.

58. Watzl refers the expressions used in the quote to Hamilton (1895), James (1890/1981), Campbell (2002), and Wu (2011). On my reading of Kant, the phenomenal contribution of attention is to modify the degree of a specific quality (i.e., consciousness), similar to what Watzl calls the degree to which "a particular aspect of the subject's apparent world is phenomenally present to her" (2017: 191). Watzl ultimately argues that it is better to conceive of the phenomenal contribution of attention not as determining degrees of a specific phenomenal quality, but rather as determining a specific phenomenal structure (2017: 95-99, 192). This is less plausible as a reading of Kant, since appeal to an irreducible and necessary structuring of phenomenal consciousness might imply a third form of intuition in addition to time and space, unless it could somehow be read as parasitic on time. (Interestingly, however, in the Kantian context the idea that intensive magnitude might require a third form of intuition was suggested by the first significant monograph on Kant's categories of quality and theory of intensive magnitude, Maier 1930). 
(Dunkelheit) and clarity (Klarheit), by analogy to the visual qualities of light and darkness. 59

\subsection{A Unified Account of Consciousness.}

Wunderlich (2005) argues that understanding consciousness in Wolffian terms, as differentiation, allows for a unified account: Pure consciousness is the differentiation of the subject from objects in general, whereas empirical consciousness is the differentiation of specific empirical objects from each other or from the subject and its representations. The Crusian account of consciousness I ascribe to Kant, however, appears to have explanatory purchase only on empirical and not on pure consciousness, since pure consciousness lacks sensation. Hence, I cannot provide a unified account of consciousness. Two responses can be made to this objection:

First, while pure consciousness does not involve determinate intuition, on closer inspection it is not entirely evident that pure consciousness is characterized as independent of sensation. Consider for instance the following passage:

If the representation of apperception, the $I$, were a concept through which anything might be thought, it could then be used as a predicate for other things, or contain such predicates in itself. But it is nothing more than a feeling of an existence without the least concept. (Prol 4:334 Footnote, my emphasis; see also A342-343/B400-401, B422-423 Footnote, A614-615/ B642-643; MAN 4:543) ${ }^{60}$

While there are certainly other passages suggesting that pure consciousness does not involve sensation, the evidence is not entirely clear-cut. ${ }^{61}$

Second, we can concede that pure consciousness does not involve sensation and still attain a unified account of consciousness: not in the inner sensation as such, but in the faculty causing the sensation, that is, the faculty of consciousness. Self-affection reveals a unified conception of consciousness beneath the duality of apperception and inner sense, insofar as the consciousness given in inner sense, that is, as inner sensation, results from the affection of inner sense by the faculty of apperception. For this reason, the so-called subjective or empirical unity

59. Explicating consciousness in terms of 'inner light' was common in Kant's immediate context; see, e.g., Wolff (1751: §§203-204), Baumgarten (1757/2013: §§514, 518). Kant uses the analogy, likening our mind to a map on which only a few points are illuminated (i.e., conscious), at Anth 7:135-136.

6o. Wunderlich (2005: 158 Footnote) notes that this passage does not fit his reading.

61. For further discussion of these passages, see Longuenesse (2017: 87-91). 
of consciousness given in inner sense is "derived . . from the original unity of consciousness" (B140), that is, from pure consciousness. For Kant, the faculty of apperception is ultimately a "distinct fundamental power [besondere Grundkraft]" (Crusius 1745: \$444) responsible for consciousness in general: either immediately (pure consciousness) or mediately, by affecting inner sense (empirical consciousness). Since 'apperception' and 'inner sense' sometimes denote not just the faculties, but also the resulting consciousness (like in Crusius), this reading explains an otherwise puzzling passage: A metaphysics lecture reports Kant as stating that "inner sense is the consciousness of our representations themselves," before adding, parenthetically, "apperception is the ground of inner sense" (MMr 29:882). "Inner sense," here meaning the inner sensations as "the consciousness of our representations themselves", indeed has apperception is its ground: By affecting (the faculty of) inner sense, apperception causally grounds state consciousness (see Section 8).

\subsection{Animal Consciousness.}

If empirical consciousness requires self-affection by the understanding, nonhuman animals (lacking an understanding) cannot have conscious states. Alternatively, if Kant does ascribe some kind of consciousness to animals (as argued, e.g., by McLear 2011), Kant will not be able to maintain a unified account of consciousness after all. Interestingly, Wolff and Crusius disagree precisely on the question of animal consciousness. Wolff argues that animals can have clear and hence conscious representations (Wolff 1751: $\$ \$ 794,901)$, while Crusius denies this (Crusius 1747: §106; see also Rüdiger 1727: 106-107). In Kant's time, as in our own, there is no agreement concerning animal consciousness. ${ }^{62}$

Kant's own position is far from clear. He occasionally denies that animals are conscious. ${ }^{63}$ However, he may be referring to self-consciousness rather than consciousness per se in these passages (see McLear 2011: 9f.). Conversely, there are a few passages where Kant appears to ascribe consciousness to animals: In a letter to Herz Kant writes that my sense data could, "if I imagine myself to be an animal," still

carry on their play in an orderly fashion, as representations connected according to empirical laws of association, and thus even have an influence on my feeling and desire, without my being aware of them (assuming that I am even conscious of each individual representation [gesetzt daß ich auch jeder einzelnen Vorstellung bewust wäre]. (Br 11:52)

62. For the contemporary debate, see, e.g., Carruthers (2000), Gennaro (2004).

63. See, e.g., $M D$ 28:689-690; $M M r$ 29:888, 29:906; $M L_{2}$ 28:594; LD 24:689, 24:702; $L W$ 24:845846; PE 29:44-45. 
However, Kant's use of "assuming" [gesetzt], and the subjunctive case, casts doubts on whether he takes what he is describing, that is, animals being conscious of their individual representations, to be a real possibility. The "degrees of cognition" passage (JL 9:64-65) has also been taken to support animal consciousness: the second degree, wahrnehmen, is representing with consciousness, while the third degree, kennen, is something that animals are said to be capable of. If these degrees are cumulative, animals must also be capable of wahrnehmen, and hence of representing with consciousness. However, animals are said to be incapable of the fourth degree (erkennen), which is explained as "kennen with consciousness." If the degrees were cumulative kennen would already include consciousness, since consciousness was the defining feature of the second degree. Hence it seems that mere kennen, which animals are capable of, must be kennen without consciousness. At the very least, this shows that the JL passage is far from conclusive evidence that Kant ascribes consciousness to animals (see further Sommerlatte in press).

\subsection{Inner Sense and a Manifold of One's Own.}

Some interpreters have argued that according to Kant, 'inner sense has no manifold of its own, ${ }^{64}$ which may be taken to entail that there are no specifically inner sensations. However, the passages cited in support of this claim say something slightly different. Kant states that

the representations of outer sense make up the proper material [eigentlicher Stoff] with which we occupy our mind" (B67), and refers to "the existence of things outside us (from which we after all get the whole matter [Stoff] for our cognitions, even for our inner sense). (Bxxxix Footnote)

The phrase 'of its own' is never used, and Kant refers to "material" [Stoff] rather than to a manifold (or, for that matter, to sensation).

These passages can be read as compatible with specifically inner sensation: Kant's point may be that the initial manifold with which we "occupy our mind" (B67) comes from outer sense alone. When we occupy our mind with this material and "determine inner sense through the manifold of given representations" (B150), that is, figuratively synthesize the material, a novel manifold of inner sensation may well-and on my reading does-arise through self-affection. ${ }^{65}$ Instructively, this is exactly how Crusius understands the relation between outer

64. See Allison (2004: 277f.), Brook (1994: 77), Dyck (2006: 39-40), Serck-Hanssen (2009: 149), Stephenson (2015), Valaris (2008: 2).

65. This reading was already endorsed by one of Kant's earliest defenders, Schmid, here in criticizing Selle: 
and inner sensation. Crusius, like Kant at B67 and Bxxxix Footnote, holds "that all our conscious ideas come from outer sensation" (Crusius 1747: §85), whereupon he explains: "Outer sensations of a suitable degree of vivacity lead to consciousness of themselves" (Crusius 1747: §85). Vivacious outer sensations "lead to" [veranlassen] consciousness for Crusius, but this means neither that there are no specifically inner sensations, nor that consciousness simply is outer sensation with a sufficient degree of vivacity. It simply means that prior outer sensations are required to trigger the process whereby inner sensations are generated. The Kant passages that have been taken to support the 'inner sense has no manifold of its own' claim can be read in the same way.

\section{Conclusion}

I have argued that state consciousness in Kant is a specific kind of inner sensation. We are not just conscious of sensory qualities; empirical consciousness itself is a specific sensory quality. Despite certain differences, a clear historical precedent for this view can be found in Crusius. It has nonetheless managed to slip beneath consideration as a possible interpretation of Kant; I hope to have remedied this lack and sketched the systematic role such an account of state consciousness plays in Kant's framework. I have shown how it elucidates Kant's account of self-affection and his distinction between mere intuition and perception. I have also indicated how the interpretation of consciousness as inner sensation allows for a richer view of Kant's empirical psychology, with regard to topics such as attention and abstraction, cognitive phenomenology, and the empirical relation to our self as a subject of power.

Several avenues of further research remain. While I have touched upon the relation of consciousness as inner sensation to apperception, some of the most central and difficult arguments of $\mathrm{KrV}$ crucially involve the distinction between inner sense and apperception, and pure and empirical self-consciousness, and these passages deserve a more thorough reexamination in light of the interpretation proposed here. I have also occasionally suggested how different aspects of Kant's position relate to recent approaches to state consciousness. An examination of the potential relevance of Kant's account for contemporary consciousness

Selle consistently speaks of sensibility in such a way that one can only think of outer sensibility, which is changed by objects outside the cognitive capacities .... No mention at all is made of those alterations that the subject itself, as an active capacity, occasions in itself (as a passive capacity) through the alterations that are received from the outside and that Kant calls inner sensations. (Schmid 1788/2000: 237)

Dirschauer (2003: 58f.) terms this self-affection "par contrecoup," see further Nabert (1924), Dyck (2006), Kraus (2016: 342), Waxman (2014: 110-111). 
studies remains to be executed. For now, I have argued in this article that Kant's account of state consciousness is both different, and of greater importance for his philosophy of mind, than commonly assumed.

\section{Acknowledgements}

For invaluable discussions, comments and feedback I am grateful to Corey Dyck, Garth Green, Toni Kannisto, Frode Kjosavik, Jacob Lautrup Kristensen, Hedda Hassel Mørch, Dennis Schulting, Camilla Serck-Hanssen, Houston Smit, several anonymous referees, and audiences in Oslo, Reykjavik, St. Andrews, and Rotterdam.

\section{Abbreviations}

Anth Anthropologie in pragmatischer Hinsicht

$\mathrm{Br} \quad$ Briefe

EE Erste Einleitung in die ,Kritik der Urteilskraft'

FM Preisschrift über die Fortschritte der Metaphysik

FP Verkündigung des nahen Abschlusses eines Tractats zum ewigen Frieden in der Philosophie

FS Die falsche Spitzfindigkeit der vier syllogistischen Figuren

JL Jäsche Logik

$\mathrm{KrV} \quad$ Kritik der reinen Vernunft

KU Kritik der Urteilskraft

LD Logik Dohna-Wundlacken

LW Logik Wiener

MAN Metaphysische Anfangsgründe der Naturwissenschaft

MD Metaphysik Dohna

$\mathrm{MK}_{2} \quad$ Metaphysik K2

$\mathrm{ML}_{1} \quad$ Metaphysik L1

$\mathrm{ML}_{2} \quad$ Metaphysik L2

MMr Metaphysik Mrongovius

MS Metaphysik der Sitten

MSV Metaphysik der Sitten Vigilantius

MVi Metaphysik Vigilantius

MVo Metaphysik Volckmann

N Nachträge zur ,Kritik der reinen Vernunft' (1. Auflage)

NG Versuch, den Begriff der negativen Größen in die Weltweisheit einzuführen

PE Philosophische Enzyklopädie

Prol Prolegomena zu einer jeden künftigen Metaphysik, die als Wissenschaft wird auftreten können

$\mathrm{R} \quad$ Reflexionen 


\section{References}

Allison, Henry E. (2004). Kant's Transcendental Idealism: An Interpretation and Defense (revised and enlarged ed.). Yale University Press. https://doi.org/10.2307/j.ctt1cc2kjc

Armstrong, David (1981). What Is Consciousness? In David Armstrong (Ed.), The Nature of Mind, and Other Essays (721-728). Cornell University Press. (Reprinted from Proceedings of the Russellian Society, 3, 65-76, 1978).

Baumgarten, Alexander (1757/2013). Metaphysics. A Critical Translation with Kant's Elucidations, Selected Notes, and Related Materials. Courtney D. Fugate and John Hymers (Eds. and Trans.). Bloomsbury.

Block, Ned (1995). On a Confusion about the Function of Consciousness. Behavioral and Brain Sciences, 18(2), 227-247. https://doi.org/10.1017/S0140525X00038188

Block, Ned (2010). Attention and Mental Paint. Philosophical Issues, 20(1), 23-63. https:// doi.org/10.1111/j.1533-6077.2010.00177.x

Brook, Andrew (1994). Kant and the Mind. Cambridge University Press. https://doi. org/10.1017/CBO9780511624629

Campbell, John (2002). Reference and Consciousness. Clarendon Press. https://doi. org/10.1093/0199243816.001.0001

Carrasco, Marisa, Sam Ling, and Sarah Read (2004). Attention Alters Appearance. Nature Neuroscience, 7(3), 308-313. https://doi.org/10.1038/nn1194

Carruthers, Peter (2000). Phenomenal Consciousness. A Naturalistic Theory. Cambridge University Press. https://doi.org/10.1017/CBO9780511487491

Chignell, Andrew (2009). Causal Refutations of Idealism. Philosophical Quarterly, 60(240), 487-507. https://doi.org/10.1111/j.1467-9213.2009.636.x

Collins, Arthur (1999). Possible Experience: Understanding Kant's Critique of Pure Reason. University of California Press.

Crusius, Christian August (1745). Entwurf der nothwendigen Vernunft-Wahrheiten. Johann Friedrich Gleditsch.

Crusius, Christian August (1747). Weg zur Gewißheit und Zuverläßigkeit der menschlichen Erkenntniß. Johann Friedrich Gleditsch.

Crusius, Christian August (1749). Anleitung über natürliche Begebenheiten ordentlich und vorsichtig nachzudencken. Anderer Theil. Johann Friedrich Gleditsch.

Crusius, Christian August (1767). Anweisung vernünftig zu leben (3rd ed.). Johann Friedrich Gleditsch.

Dirschauer, Stéphane (2003). La théorie kantienne de l'auto-affection. Kant-studien, 95(1), 53-85. https://doi.org/10.1515/kant.2004.007

Droege, Paula (2003). Caging the Beast. A Theory of Sensory Consciousness. John Benjamins. https://doi.org/10.1075/aicr.51

Dyck, Corey W. (2006). Empirical Consciousness Explained: Self-Affection, (Self-)Consciousness, and Perception in the B Deduction. Kantian Review, 11(1), 29-54. https:// doi.org/10.1017/S1369415400002235

Dyck, Corey W. (2011). A Wolff in Kant's Clothing: Christian Wolff's Influence on Kant's Accounts of Consciousness, Self-Consciousness, and Psychology. Philosophy Compass, 6(1), 44-53. https://doi.org/10.1111/j.1747-9991.2010.00370.x

Dyck, Corey W. (2014). Kant and Rational Psychology. Oxford University Press. https://doi. org/10.1093/acprof:oso/9780199688296.001.0001

Dyck, Corey W. (2016). Spontaneity before the Critical Turn: The Spontaneity of the Mind 
in Crusius, the Pre-Critical Kant, and Tetens. Journal of the History of Philosophy, 54(4), 625-648. https://doi.org/10.1353/hph.2016.0073

Frierson, Patrick R. (2014). Kant's Empirical Psychology. Cambridge University Press. https://doi.org/10.1017/CBO9781139507035

Gardner, Sebastian (1999). Routledge Philosophy Guidebook to Kant and the Critique of Pure Reason. Routledge.

Gennaro, Rocco J. (2004). Higher-Order Thoughts, Animal Consciousness, and Misrepresentation: A Reply to Carruthers and Levine. In Rocco Gennaro (Ed.), HigherOrder Theories of Consciousness (45-66). John Benjamins. https://doi.org/10.1075/ aicr.56.05gen

Grau, Kurt Joachim (1916). Die Entwicklung des Bewußtseinsbegriffes im XVII. und XVIII. Jahrhundert. Verlag von Max Niemeyer.

Hamilton, William (1895). Notes and Supplementary Dissertations. In Works of Thomas Reid (8th ed., 741-1034). Maclachlan and Stewart.

Hanna, Robert (2013). Transcendental Idealism, Phenomenology, and the Metaphysics of Intentionality. In Karl Ameriks (Ed.), The Impact of Idealism: The Legacy of PostKantian German Thought (Vol 1., 191-224). Cambridge University Press. https://doi. org/10.1017/CBO9781139626675.009

Harman, Gilbert (1990). The Intrinsic Quality of Experience. Philosophical Perspectives, 4, 31-52. https://doi.org/10.2307/2214186

Indregard, Jonas Jervell (2017a). A Gradual Reformation: Empirical Character and Causal Powers in Kant. Canadian Journal of Philosophy. Advance online publication. http:// dx.doi.org/10.1080/00455091.2017.1370942.

Indregard, Jonas Jervell (2017b). Self-Affection and Pure Intuition in Kant. Australasian Journal of Philosophy, 95(4), 627-643. http://dx.doi.org/10.1080/00048402.2017.1286511

James, William (1890/1981). The Principles of Psychology. Harvard University Press.

Jankowiak, Tim (2014). Sensations as Representations in Kant. British Journal for the History of Philosophy, 22(3), 492-513. http://dx.doi.org/10.1080/09608788.2014.913550

Kant, Immanuel (1900-). Kants gesammelte Schriften. Akademie der Wissenschaften (Eds.). De Gruyter.

Kant, Immanuel (1992-). The Cambridge Edition of the Works of Immanuel Kant. Paul Guyer and Allen Wood (Eds.). Cambridge University Press.

Kitcher, Patricia (2011). Kant's Thinker. Oxford University Press. https://doi.org/10.1093/ acprof:oso/9780199754823.001.0001

Kraus, Katharina (2016). Quantifying Inner Experience? - Kant's Mathematical Principles in the Context of Empirical Psychology. European Journal of Philosophy, 24(2), 331-357. https://doi.org/10.1111/ejop.12068

Kriegel, Uriah (2003). Consciousness as Sensory Quality and as Implicit SelfAwareness. Phenomenology and the Cognitive Sciences, 2(1), 1-26. https://doi. org/10.1023/A:1022912206810

La Rocca, Claudio (2008). Unbewußtes und Bewußtsein bei Kant. In Manfred Kugelstadt (Ed.), Kant-Lektionen. Zur Philosophie Kants und zu Aspekten ihrer Wirkungsgeschichte (47-68). Königshausen \& Neumann.

Locke, John (1694/1975). An Essay Concerning Human Understanding. Peter H. Nidditch (Ed.). Oxford University Press.

Longuenesse, Béatrice (2017). I, Me, Mine: Back to Kant, and Back Again. Oxford University Press. https://doi.org/10.1093/acprof:oso/9780199665761.001.0001 
Lycan, William G. (1995). Consciousness as Internal Monitoring. Philosophical Perspectives, 9, 1-14. https://doi.org/10.2307/2214210

Lyons, William (1986). The Disappearance of Introspection. MIT Press.

Maier, Anneliese (1930). Kants Qualitätskategorien. Metzner.

Malebranche, Nicolas (1678/1997). The Search after Truth. Thomas M. Lennon and Paul J. Olscamp (Trans.). Cambridge University Press.

Matherne, Samantha (2015). Images and Kant's Theory of Perception. Ergo, 2(29), 737777. http://dx.doi.org/10.3998/ergo.12405314.0002.029

McLear, Colin (2011). Kant on Animal Consciousness. Philosophers' Imprint, 11(15), 1-16. http://hdl.handle.net/2027/spo.3521354.0011.015

Meier, Georg Friedrich (1752). Auszug aus der Vernunftlehre. Gebauer.

Merritt, Melissa McBay (2014). Kant on the Pleasures of the Understanding. In Alix Cohen (Ed.), Kant on Emotion and Value (126-145). Palgrave Macmillan.

Merritt, Melissa McBay and Markos Valaris (2017). Attention and Synthesis in Kant's Conception of Experience. Philosophical Quarterly, 67(268), 571-592. https://doi. org/10.1093/pq/pqw085

Mohr, Georg (1991). Das sinnliche Ich. Innerer Sinn und Bewußtsein bei Kant. Königshausen \& Neumann.

Nabert, Jéan (1924). L'expérience interne chez Kant. Revue de Métaphysique et de Morale, $31(2), 205-268$.

Paton, Herbert James (1936/1976). Kant's Metaphysic of Experience. A Commentary on the First Half of the Kritik der reinen Vernunft (2 Vols.). Humanities Press.

Renz, Ursula (2015). Becoming Aware of One's Thoughts: Kant on Self-Knowledge and Reflective Experience. In A. Colliva, V. Munz, and D. Moyal-Sharrock (Eds.), Mind, Language and Action: Proceedings of the $36^{\text {th }}$ International Wittgenstein Symposium (5816oo). De Gruyter.

Rosenthal, David (1990). A Theory of Consciousness. ZIF Report 40. Centre for Interdisciplinary Research.

Rosefeldt, Tobias (2000). Das logische Ich. Kant über den Gehalt des Begriffes von sich selbst. Philo.

Rüdiger, Andreas (1727). Herrn Christian Wolffens Meinung von dem Wesen der Seele und eines Geistes überhaupt, und D. Andreas Rüdigers Gegen-Meinung. Heinsius.

Schepers, Heinrich (1959). Andreas Rüdigers Methodologie und ihre Voraussetzungen. Kölner Universitäts-Verlag.

Schmaltz, Tad M. (1996). Malebranche's Theory of the Soul. A Cartesian Interpretation. Oxford University Press.

Schmid, Carl Christian Erhard (1788/200o). Dictionary for the Easier Use of Kant's Writings. Appendix: Some Remarks about Empiricism and Purism in Philosophy Occasioned by Selle's Principles of Pure Philosophy. In Brigitte Sassen (Ed. and Trans.), Kant's Early Critics: The Empiricist Critique of the Theoretical Philosophy (233-254). Cambridge University Press.

Schmitz, Friederike (2015). On Kant's Conception of Inner Sense: Self-Affection by the Understanding. European Journal of Philosophy, 23(4), 1044-1063. https://doi. org/10.1111/ejop.12025

Schulting, Dennis (2012a). Kant's Deduction and Apperception: Explaining the Categories. Palgrave Macmillan.

Schulting, Dennis (2012b). Non-Apperceptive Consciousness. In Piero Giordanetto, Ric- 
cardo Pozzo, and Marco Sgarbi (Eds.), Kant's Philosophy of the Unconscious (271-304). De Gruyter. https://doi.org/10.1515/9783110265408.271

Schulting, Dennis (2015). Transcendental Apperception and Consciousness in Kant's Lectures on Metaphysics. In Robert Louden (Ed.), Reading Kant's Lectures (89-113). De Gruyter. https://doi.org/10.1515/9783110345339-010

Serck-Hanssen, Camilla (2009). Kant on Consciousness. In Sara Heinämaa and Martina Reuter (Eds.), Psychology and Philosophy (139-158). Springer.

Sommerlatte, Curtis (in press). Erkenntnis in Kant's Logical Works. In Natur und Freiheit: Akten des XII. Internationalen Kant-Kongresses 2015.

Stephenson, Andrew (2015). Kant on the Object-Dependence of Intuition and Hallucination. Philosophical Quarterly, 65(260), 486-508. https://doi.org/10.1093/pq/pqu100

Sturm, Thomas and FalkWunderlich(2010). Kantand theScientificStudy of Consciousness. History of the Human Sciences, 23(3), 48-71. https://doi.org/10.1177/0952695110363355

Thiel, Udo (2011). The Early Modern Subject. Self-Consciousness and Personal Identity from Descartes to Hume. Oxford University Press. https://doi.org/10.1093/acprof:o so/9780199542499.001.0001

Thomasius, Christian (1691). Einleitung zu der Vernunfft-Lehre. Salfeld.

Tiedemann, Dieterich (1777). Untersuchungen über den Menschen. Erster Theil. Weidmann und Reich.

Tolley, Clinton (2013). The Non-Conceptuality of the Content of Intuitions: A New Approach. Kantian Review, 18(1), 107-136. https://doi.org/10.1017/S1369415412000313

Tolley, Clinton (in press). The Meaning of 'Perception' in Kant and His Historical Context. In Natur und Freiheit: Akten des XII. Internationalen Kant-Kongresses 2015.

Valaris, Markos (2008). Inner Sense, Self-Affection, and Temporal Consciousness in Kant's Critique of Pure Reason. Philosophers' Imprint, 8(4), 1-18. http://hdl.handle. net/2027/spo.3521354.0008.004

Watkins, Eric (2005). Kant and the Metaphysics of Causality. Cambridge University Press.

Watzl, Sebastian (2017). Structuring Mind: The Nature of Attention and How It Shapes Consciousness. Oxford University Press. https://doi.org/10.1093/acprof:o so/9780199658428.001.0001

Waxman, Wayne (2014). Kant's Anatomy of the Intelligent Mind. Oxford University Press.

Wolff, Christian (1738). Psychologia Empirica (2nd ed.). Renger.

Wolff, Christian (1740). Psychologia Rationalis (2nd ed.). Renger.

Wolff, Christian (1751). Vernünfftige Gedancken von Gott, der Welt und der Seele des Menschen, auch allen Dingen überhaupt (11th ed.). Renger.

Wu, Wayne (2011). What Is Conscious Attention? Philosophy and Phenomenological Research, 82(1), 93-120. https://doi.org/10.1111/j.1933-1592.2010.00457.x

Wuerth, Julian (2014). Kant on Mind, Action, and Ethics. Oxford University Press. https:// doi.org/10.1093/acprof:oso/9780199587629.001.0001

Wunderlich, Falk (2005). Kant und die Bewußtseinstheorien 18. Jahrhunderts. De Gruyter. https://doi.org/10.1515/9783110902426

Zinkin, Melissa (2012). Kant on Negative Magnitudes. Kant-studien, 103(4), 397-414. https://doi.org/10.1515/kant-2012-0030 
